\title{
Analysis of Effect of Ethics Education and Love of Money Perception of Accounting Students in the Preparation of Financial Statements
}

\author{
${ }^{*}$ Hj Marwah Yusuf, Anim Wiyana \\ Hasanuddin University, Indonesia \\ *marwah_yusuf@yahoo.com
}

\begin{abstract}
This study analyzed the influence of ethics education and love of money on student perceptions of accounting in preparing the financial statements. The study population, the entire accounting student at the State University (PTN) in Makassar. Sampling was purposive sampling method, and is chosen, students who have already taken courses and professional ethics. Methods of data collection in this study, is a questionnaire, after the data is collected and analyzed by SPSS. In conclusion, there is no influence of variables and students' perceptions of ethics education in the preparation of financial statements. With figures from the calculation of the probability of the correlation between the variables of $0.300<0,05.20$. No influence of variables Love of Money and perceptions of students in the preparation of financial statements with the number probability $0,201<0,05.30$. There was no difference between the perception of the preparation of financial statements accounting students who have not taken the ethics education courses and students who have taken courses accounting ethics education. Figures probability variable correlation calculation results of $0.201<0.05$.
\end{abstract}

Keywords: Ethics, Perception, Love of Money, Student, Financial Statements

\section{Introduction}

Background: The financial report is one of the media used to connect the parties with an interest in the company. In this case, the parties concerned are the investors, and the owner of the company itself. In its establishment, the financial statements cannot be separated from the behavior of accountants in the company that is in connection with the accounting policies. The process of preparation of financial statements in Indonesia based on the Financial Accounting Standards (IFRSs), and generally accepted SAK; this provides the opportunity for management to do and choose the method of accounting to be applied within the company. In Indonesia alone financial statements still need to be upgraded and improved. One of the factors that still need to be improved to improve the quality of financial reporting in Indonesia is related to ethics and positive attitude accountant Indonesia. With a variety of reasons and purposes either right or wrong sometimes financial statements which have been made by accountants deviates from ethics and positive attitude of an accountant. Not surprisingly, since the first ethical accountants are always highlighted in presenting the financial statements. Since the bankruptcy of major US companies such as Enron, Worldcom, the accounting profession has experienced a crisis of confidence in its ability to regulate its members and provide reliable financial reports to the public. That led to renewed government legislation such as Sarbanes-Oxley (SOX) Act in 2002. However, many things are not set in the code of conduct and SOX. Studies show that the accountant with a higher moral reasoning is considered a state or behavior violation as something unethical when compared to accountants who have lower moral reasoning.

In Indonesia big cases like PT Waskita in world public accountant affect the user's perception of the reliability of financial statements financial statements. With the big cases, the required effort to restore public confidence in the accounting profession. Therefore, education on ethics must be done properly to accounting students before they enter the workforce. The occurrence of multiple ethics violations that occurred in Indonesia, whether undertaken by public accounting, internal accounting, and government accountants. Supposedly this kind of thing would not happen if every accountant and aspiring accountant have knowledge; understanding and can adequately implement ethics in carrying out his duties as a professional accountant. An accountant job to be done with a fully professional attitude based on moral and ethical standards that exist. With the attitude of the professional accountant will be able to face the pressure arising from itself or 
from external parties, where the ability of an accountant to be able to understand and be sensitive to ethical issues are also greatly influenced by the environment in which it is located. In this case there is one factor that can influence the behavior of an accountant is the educational environment.

Wyatt (2004) mentions that there are weaknesses in the accountant is; individual and corporate greed, the provision of services which reduce the independence, the attitude too 'soft' on the client and avoid participation in the existing accounting rules. Wyatt added that to avoid these things, accounting educators should give greater attention in accounting education on two things, namely the appreciation of the accounting profession and the appreciation of the ethical dilemmas (ethical dilemmas). It can be manifested in a subject, the method of teaching to the curriculum which is based on ethical values and morals. Accounting education in Indonesia aims to produce graduates who are ethical and moral high. Various attempts were made to introduce the values and ethics of accounting profession to students. In the development of accounting education based on ethics is necessary to have feedback (feedback) about the current conditions, i.e. whether the accounting education in Indonesia has enough to form positive values accounting students. International Federation of Accountants (IFAC) in 2010 has published seven international educational standards (International Education Standard / IES). From the seventh standard, the standard number 4 (IES 4) states that accounting education programs should provide a framework of values. Ethics and professional attitude to train prospective accountants' professional judgment that can act ethically in the middle of the profession and the public interest. With the accountant high ethical and moral, the expected goals of the financial statements can be achieved, namely to provide information needed by the user.

Because of the importance of ethics in the profession, making the accounting profession focuses on ethical perceptions of accounting students as a starting point to improve the perception of the profession. Elias \& Magdy (2010) says that there is still much needed research on the socialization of ethics in accounting students. There are various factors that can affect a person's perception of ethical violations. One such factor is money. Money is a very important aspect in our daily lives. Understanding the importance of money has increased significantly in the United States and around the world (Tang et al., 2004). McClelland (1967) in Elias (2008) says that although money is used universally, the meaning and importance of money is not universally accepted. In the US, a person's success is measured by the amount of money and the revenue generated. Research conducted by Tang et al., (2004), which examines a new psychological variable that individual love of money (love of money). Some common belief says that the love of money is the root of all evil (Tang, 2007). Tang (2007) summarize the definition of love of money as: 1) measurement of the value of a person, or a desire for money but not their needs; 2) the meaning and importance of a person's money and personal behavior towards money. Tang and Chen (2008) defines the love of money as a person's behavior towards money; one's understanding of the money; one's desires and aspirations of the money; variable multi-dimensional difference a person, an idea which is composed of several sub-ideas or factors.

Research conducted Intani \& Suhendra (2009) proved that there is a significant difference between students who have taken ethics education to students who have not taken the ethics education in the preparation of financial statements. While Charismawati (2011) studies proved that there is a relationship between the level of love of money on accounting students with their ethical perception. The greater the love of money the student level the lower the level of their ethical perception. There is a shortage of research on potential ethical education and love of money in the preparation of financial statements that needed further investigation. This study contains the analysis of the influence of ethics education and love of money toward the perception of students in the preparation of financial statements, which is the development of research Charismawati (2011), Elias \& Magdy (2010) and Intani \& Suhendra, (2009). The interest of researchers to the problem because of the crisis of public confidence in the accounting profession and performed to detect whether the factor of ethics education and love of money affects the perception of the preparation of the financial statements.

Problem Formulation: Based on the background that has been stated above, the main problems to be addressed in this study are:

- What is the influence of ethics education on students' perceptions of accounting in preparing the financial statements?

- Is the love of money to influence students' perceptions of accounting in preparing the financial statements? 
- Are there differences in perceptions regarding the preparation of financial statements between accounting students who have not taken courses accounting ethics education and students who have taken courses ethics education?

Objective: The purpose of this research was conducted:

- To analyze the influence of ethics education on students' perceptions of accounting in preparing the financial statements.

- To analyze the influence of love of money on student perceptions of accounting in preparing the financial statements.

- To analyze the differences in the perception of the preparation of financial statements between accounting students who have not taken courses accounting ethics education and students who have taken courses ethics education.

\section{Literature Review}

Understanding Financial Statements: The financial report is a report on the financial position and performance ability of the company as well as other information required by the users of accounting information both internally and externally. The function of the financial statements is to provide information concerning the financial position (assets, liabilities and equity) and provides information on the performance and changes in financial position of an enterprise that is useful to the users of accounting information in decision making. Therefore, the financial statements must be able to provide information that is more realistic and can describe the condition of the actual state of the company that approach. According to Statement of Financial Accounting (SFAC) No. 2 Qualitative characteristics of accounting information is as follows:

- Relevant means, the capacity of information that can push a decision when utilized by the user to predict the outcome of interest in the future based on past and current events. There are three main characteristics:

a. Timeliness (timeliness), which is information that is ready to use the user before losing meaning and capacity in decision making.

b. Predictive value (predictive value), which information can help users in making predictions about the outcome of events past, present and future.

c. Feedback (feedback value), namely the quality of information that enables the user can confirm the expectations that have occurred in the past.

- Reliable, is the quality of information that is guaranteed to be free of errors and irregularities or bias and has been properly assessed and presented in accordance with its objectives. Reliable has three main characteristics:

a. Can be checked (verifiability), which is a consensus in the choice of accounting measurement that can be assessed by its ability to assure that whether the information presented is based on certain methods give the same result if verified by the same method by an independent party.

b. Honesty presentation (representation faithfulness), namely the lack of compatibility between accounting numbers and descriptions and sources.

c. Neutrality (neutrality), neutral accounting information intended for the general needs of the users and regardless of assumptions about the specific needs and desires of the user certain specific information.

- 3. Power of Appeals (comparability), accounting information which can be compared to present the similarities and differences that arise from the basic similarities and differences in the company and transaction basis and not solely from differences in accounting treatment.

- Consistency, the uniformity in the determination of accounting policies and procedures do not change from period to period.

Definition of Ethics: The word is often confused with the term ethics etiquette, ethical, ethos and code of ethics or code of ethics. Ethics is the study of what is good and bad. Etiquette is teaching manners that apply when people get along or in groups with other human beings. Ethical means in accordance with the moral teachings. Ethos means basic attitude of a person in a particular field. Code of conduct or code of ethics means 
the list of obligations in a professional stints compiled by members of the profession and the binding members in carrying out their duties. Duska \& Brenda (2011) Ethics is the principle governing the behavior of individuals or groups. Personal ethics are rules within the scope of individuals to live a private life. For example: Accounting Ethics is a set of rules that govern the actions of professional accountants. Fritzsche $(2005 ; 20)$ Ethical behavior is critical to business success in the long term, both from the perspective of macro and micro perspectives.

Definition of Perception: Perception is the process to understand the environment includes objects, people, and symbols or signs involving cognitive processes (introduction). Cognitive process is the process by which individuals give meaning through interpretation of the stimulus (stimulus) that arise from objects, people, and certain symbols. In other words, perception includes the reception, organization, and interpretation of the stimulus that has been organized in a way that can affect the behavior and shape attitudes. This happens because the perception involves the interpretation of the individual to a particular object, and then each object will have a different perception despite seeing the same object (Gibson, 1996 in Rahmawati \& Sulardi, 2003). Gibson in (Rahmawati \& Sulardi, 2003) states there are several important factors that lead to specific individual differences in the behavior of perception, attitude, personality and learning. Through an understanding of individual perceptions, one can predict how an individual's behavior is based on their perception of what reality was, not about what reality itself (Rahmawati \& Sulardi, 2003). One of the psychological factors that influence ethical perception is the love of money or love of the individual against the money. Someone who has a love of high money often have a lower perception of ethical and would negatively affect the decision-making less ethical in his work.

\section{Figure 1: Factors Affecting Perception}

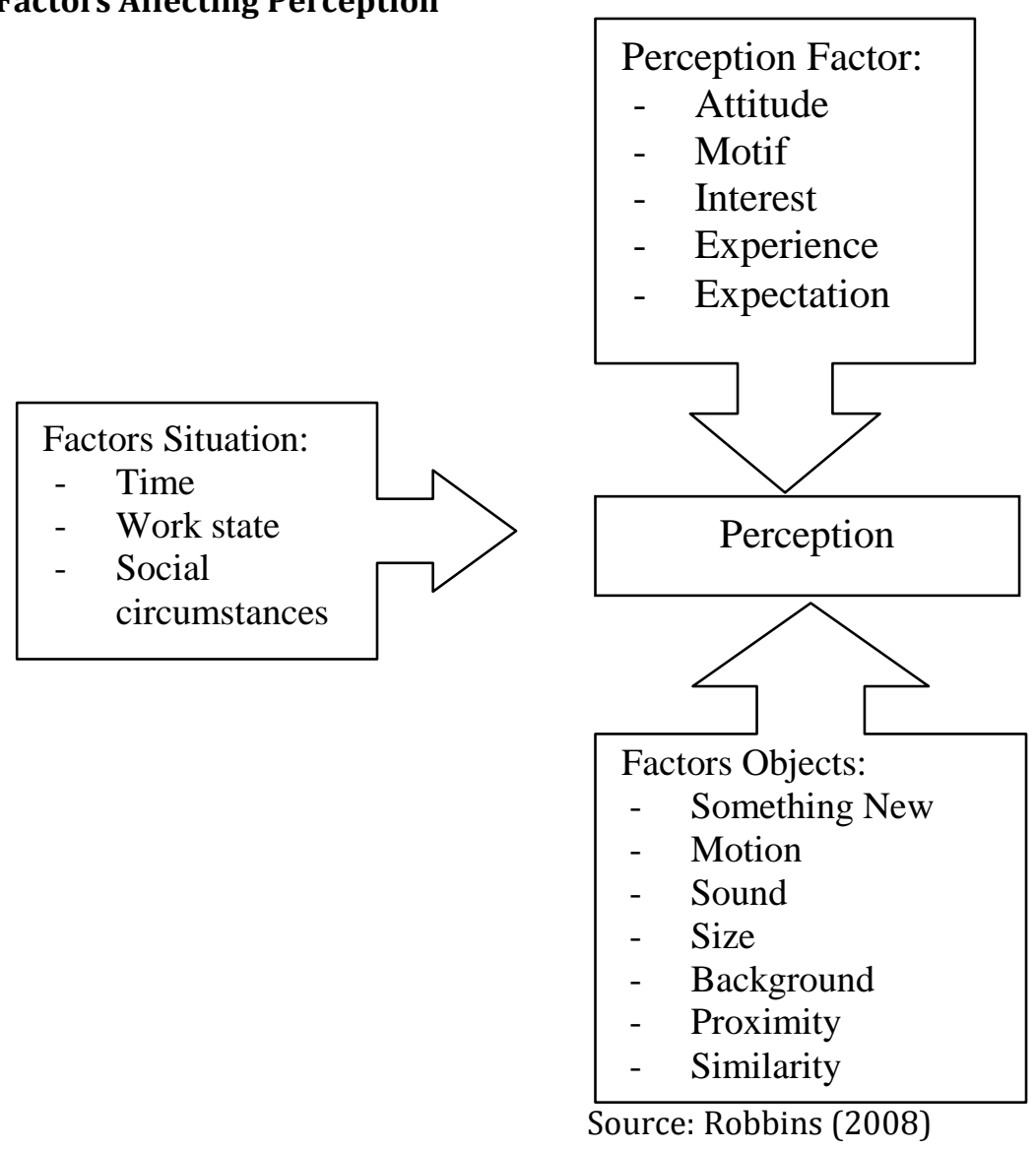

The love of money: Money is a very important aspect in our daily lives. Rubenstein (1981) in Elias \& Magdy (2010) found in the United States, success is measured by money and income. Although the money is used universally, the meaning and importance of money is not universally accepted. Tang et al. (2005) in Elias \& 
Magdy (2010) argue that attitudes toward money are learned through socialization processes are established in childhood and maintained in adult life. In the business world, managers use the money to attract, retain, and motivate employees (Milkovich and Newman, 2002 in Elias \& Magdy, 2010). Because of the importance of money and different interpretations, Tang (1992) in Elias \& Magdy (2010) introduced the concept of the love of money for psychological literature. This concept measures the subjective feeling of someone about money. Research has shown that the love of money associated with some desirable organizational behaviors and unwanted. Tang et al. (2000) in Elias \& Magdy (2010) found that mental health professionals with the love of money that low has a low turnover intent, even with low job satisfaction. Tang and Chiu (2003) in Elias \& Magdy (2010) theorized that the concept of love of money is related to the concept of greed. They found that employees in Hong Kong with a high love of money is less satisfactory in work compared with their peers. Chen and Tang (2006) suggests that the relationship may lead to unethical behavior. In fact, Tang and Chiu (2003) in Elias \& Magdy (2010) also find a direct path between the love of money and unethical behavior among employees in Hong Kong.

\section{Methodology}

Stages Research: To answer the research problems and realize the objectives of the study, the stages of research can be done as follows:

- Develop a proposal and submit a research proposal

- Procure means of research, in the form of a questionnaire compiled research, procurement of materials and equipment

- Perform data collection, through questionnaires on the target respondents.

- Perform data tabulation

- Perform data analysis and interpretation of research results

- Develop research report

- Publication of research reports

Location Research: This research was conducted at the State University accounting students (PTN) in Makassar. Makassar was chosen as the study site because it is a barometer of education in eastern Indonesia.

Variables Observed / Measured: The following operational definition and measurement of variables in this study:

A. Education Ethics: In this study, accounting students who have taken the course yet and professional ethics. No specific measures in terms of impact assessment for ethics education. For subjects who do not take ethics coded 0 and that has taken the course of professional ethics coded 1.

B. Love of Money: Theory love of money trying to measure subjective feelings someone about money. Money Ethic Scale (MES) developed by Tang et al. (2004) was used to measure the love of money. This scale measures the ethical significance of how one judges the money. The questionnaire produced six factors were identified as follows: good, evil, achievement, respect (self-esteem), budget, and freedom (power). Respondents expressed their agreement or disagreement with each statement on a seven-point scale ranging from 1 (strongly disagree) to 5 (strongly agree) and a score is calculated separately for each factor.

C. Perception of Financial Statements: An attitude or valuation of accounting students in the preparation of financial statements consisting of misstatement (misstate), to measure tanggggungjawab manager (responsibility), to measure the costs and benefits (cost and benefit) for measuring pemehaman managers, as well as to measure the disclosure of sensitive information (disclosure). Respondents noted their perceptions with the Likert scale with 5 categories of research that strongly disagree to strongly agree.

Model Used: In this study receipts two independent variables: education ethics and love of money that affect the dependent variable in this case the perception of accounting students in the preparation of financial statements.

Design Research: This study merupakakan survey research on ethics education and love of money that affect perspsi students in the process of preparing financial statements. Source of data obtained from: 1). Primary data, i.e. data obtained from the first source of the individual in the form of questionnaires. In this study, the 
data obtained in the form of respondents accounting students who have or have not taken courses in professional ethics State University (PTN), 2). Secondary data. Secondary data in this study was obtained from the results of the research, literature, journals, and libraries associated with this research

\section{Figure 2: Framework}

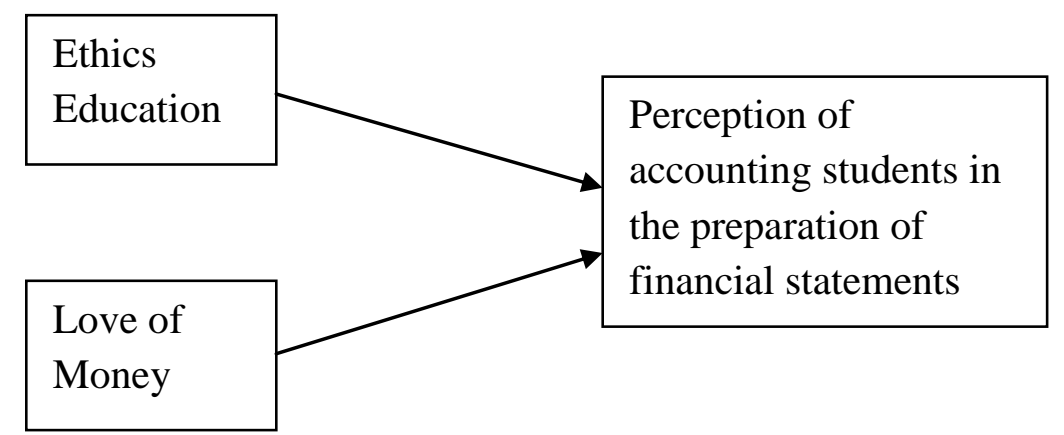

Data Collection Techniques: The population in this study are all accounting students at the State University (PTN). Sampling was purposive sampling method and consideration of sampling is selected students who have taken the course yet and professional ethics. Methods of data collection in this study was a questionnaire, using a list of questions that have been prepared to be filled by the respondents who selected as a sample.

Data Analysis: Data analysis methods used in this study, namely:

A. Quality Test Data: Test reliability and validity test was used to test the quality of the research instrument in the form of a questionnaire. Test reliability in this study is intended to determine the extent of the measurement results remain consistent, if the measurements were taken twice or more of the symptoms are the same as using the same gauge as well. Researchers conducted a reliability test by calculating Cronbach Alpha of each item in a variable. Instruments used in the variable is said to reliable if it has more and Cronbach's Alpha of 0.60 (Nunnally, 1978). The test of the validity of this study is intended to determine the degree of homogeneity of the research data so that the instrument can measure what should be measured. This test is done by correlating the value of each item by item with a total score Pearson Correlation analysis tools. A variable is said to pass the test of validity if all Pearson Correlation coefficients of each grain items with a total score is significant.

B. Descriptive Analysis: Descriptive analysis is the analysis used to describe or explain an idea of the respondents surveyed, the data concerning information on the opinions of respondents who described the descriptive statistics in the form of a frequency distribution that can describe the average value, the highest value, the lowest value both in value absolute and percentage values (relative) of several variables relevant research presented.

C. Analysis Verification: Verification analysis is used in order to verify or prove the research hypothesis. Of variables that have been determined to be analyzed using the SPSS computer software to produce a print-out for analysis. The analysis tool that is used to test the research hypothesis is multiple regression analysis of $\mathrm{T}$ test and $\mathrm{F}$ test multiple regression analysis aims to determine the direction of the relationship between each independent variable with the dependent variable.

The regression equation is as follows:

$\mathrm{Y}=\alpha+\mathrm{b} 1+\mathrm{b} 2 \mathrm{X} 1 \mathrm{X} 2+\mathrm{e}$

Specification:

Y: Student Perceptions in The Preparation of Financial Statements

$\mathrm{X} 1$ : Ethics Education

X2: Love Of Money

$\alpha$ : Constant

e: error

b1, b2: regression coefficient of each independent variable. 


\section{Analysis and Discussion}

Description of Research Object: In this study, using analytic descriptive research with cross sectional method, the power is obtained simultaneously through questionnaires college. Samples were selected from the study population to obtain primary data by means of questionnaires were accounting students who have and have not take a course in professional ethics / business. The area located in Makassar. The questionnaire was given directly to accounting students Tier 1 beside Universities. Questionnaires distributed consist of preparation of financial statements by the number of questions asked as many as 13 items or the questions and Love of Money by the number of questions asked 10 items or the questions. The questionnaire was distributed to the three colleges came directly concerned. Once the questionnaire is completed filled, questionnaires were taken back by the author go directly to the College.

\section{Description of Research}

Distribution and Acceptance Questionnaire Respondents: In table 1 it can be seen the details of the deployment and acceptance questionnaire.

Table 1: Distribution and Acceptance Questionnaire

\begin{tabular}{|c|c|c|c|c|c|}
\hline No. & Higher Education & $\begin{array}{l}\text { Questionnaires } \\
\text { were } \\
\text { distributed }\end{array}$ & $\begin{array}{l}\text { Questionnaires } \\
\text { Received }\end{array}$ & $\begin{array}{l}\text { Questionnaires } \\
\text { which can be } \\
\text { processed }\end{array}$ & $\begin{array}{l}\text { Percentage } \\
\text { (\%) }\end{array}$ \\
\hline 1. & $\begin{array}{ll}\text { Universitas } & \text { Negeri } \\
\text { Hasanuddin } & \end{array}$ & 35 & 33 & 32 & $32 \%$ \\
\hline 2. & $\begin{array}{l}\text { Universitas Negeri } \\
\text { Makassar }\end{array}$ & 35 & 31 & 28 & $28 \%$ \\
\hline 3. & $\begin{array}{l}\text { Politeknik Negeri } \\
\text { Ujung Pandang }\end{array}$ & 35 & 27 & 25 & $25 \%$ \\
\hline & Total & 105 & 91 & 85 & $85 \%$ \\
\hline
\end{tabular}

Source: Primary data is processed (2013)

Primary data were obtained and will be processed in this research is through a survey of State universities in Makassar. Based on the above table 4.1 questionnaires distributed were 105 pieces and return as many as 91 pieces, the questionnaire cannot be used for data processing as much as 6 units because of incomplete filling. So that the questionnaire can be used as many as 85 pieces of this research.

Identity Frequency Distribution of Respondents: In this study, the primary data to be processed is obtained through questionnaires with closed questions. Questionnaire data to be processed is a cumulative data or a combination of the above answers the question whether the questionnaires have not been well studied ethics at 3 Universities. After the questionnaires were given to the 3rd State Universities have sufficient quota, next is researching and managing identity data of respondents who aim to determine the number of respondents who did the questionnaires based on the classification of students who have not been well studied ethics. Once the data is processed, it can be seen that the number of respondents who conduct questionnaires for research purposes as many as 85 students. Identity of the frequency distribution of respondents by students who have not been well studied ethics can be seen in the table below:

Table 2: Distribution and Acceptance Questionnaire

\begin{tabular}{|c|c|c|c|c|c|}
\hline No. & Higher Education & \multicolumn{2}{|c|}{ Ethics Education } & $\begin{array}{l}\text { Already } \\
\text { percentage }(\%)\end{array}$ & $\begin{array}{l}\text { There } \\
\text { Percentage (\%) }\end{array}$ \\
\hline 1. & $\begin{array}{l}\text { Universitas } \\
\text { Hasanuddin }\end{array}$ & 15 & 17 & $17,65 \%$ & $20,00 \%$ \\
\hline 2. & Universitas Negeri Makassar & 16 & 12 & $18,82 \%$ & $14,12 \%$ \\
\hline 3. & $\begin{array}{l}\text { Politeknik Negeri } \quad \text { Ujung } \\
\text { Pandang }\end{array}$ & 15 & 10 & $17,65 \%$ & $11,76 \%$ \\
\hline & Total & 46 & 39 & $54,12 \%$ & $45,88 \%$ \\
\hline
\end{tabular}

Source: Primary data is processed (2013) 
From the data obtained that the respondents who had ethics education of 46 students or by $54.1 \%$ and that have not been studying ethics are 39 students or by $45.88 \%$. Based on the above table, it can be explained that the majority of respondents are already studying ethics.

\section{Test Data Quality}

Validity: The test of the validity of this study is intended to determine the degree of homogeneity of the research data so that the instrument can measure what should be measured. This test is done by correlating the value of each item by item with a total score Pearson Correlation analysis tools. A variable is said to pass the test of validity if all Pearson Correlation coefficients of each grain items with a total score is significant. Significant level used in testing the validity of this study is someone $0.05(\alpha=5 \%)$, whereby when the profitability obtained from the correlation coefficient each question is smaller than 0.05 , then the question is valid. Or in other ways that the correlation coefficient obtained more than $r$ table then the question is valid. Results SPSS for Windows Version to test the validity of the instrument questionnaire data can be seen in the following table:

a. Variable Perception of Financial Statements

\section{Table 3: Validity Test Results Perceptions of Financial Statements}

\begin{tabular}{cllc}
\hline 0 & Coefficient r & Conclusion \\
\hline 1. & 0.801 & Valid \\
2. & 0.588 & Valid \\
3. & 0.791 & Valid \\
4. & 0.888 & Valid \\
5. & 0.647 & Valid \\
6. & 0.793 & Valid \\
7. & 0.831 & Valid \\
8. & 0.592 & Valid \\
9. & 0.829 & Valid \\
10. & 0.688 & Valid \\
11. & 0.840 & Valid \\
12. & 0.653 & Valid \\
13. & 0.727 & Valid \\
\hline
\end{tabular}

Source: SPSS processing results (processed)

Validity analysis table above shows that all of the questions is greater than the value of $r$ table $>0.05$ then the variable perception questionnaire accounting students in the preparation of the financial statements or a positive correlation coefficient of $r$ count $>r$ table. Thus, all of the questions can be declared invalid and all items of the statement can be used and can be trusted.

\section{Variable Love of Money}

Table 4: Results Validity Love of Money

\begin{tabular}{clc}
\hline Item Question & Coefficient $\mathbf{r}$ & Conclusion \\
\hline 1. & 0.804 & Valid \\
2. & 0.628 & Valid \\
3. & 0.730 & Valid \\
4. & 0.779 & Valid \\
5. & 0.672 & Valid \\
6. & 0.729 & Valid \\
7. & 0.812 & Valid \\
8. & 0.875 & Valid \\
9. & 0.838 & Valid \\
10. & 0.881 & Valid \\
\hline Source: SPSS processing results (processed)
\end{tabular}

Source: SPSS processing results (processed) 
Validity analysis table above shows that all of the questions is greater than the value of $r$ table> 0.05 , the questionnaire variables influence value for money in the financial statements or a positive correlation coefficient of $r$ count $>r$ table. Thus, all of the questions can be declared invalid and all items of the statement can be used and can be trusted.

Test Reliability: Test reliability in this study is intended to determine the extent of the measurement results remain consistent, if the measurements were taken twice or more of the symptoms are the same as using the same gauge as well. Researchers conducted a reliability test by calculating Cronbach Alpha of each item in a variable. Instruments used in the variable is said to reliable (reliable) if it has more and Cronbach's Alpha of 0.60 (Nunnally, 1978). Results SPSS for Windows Version to test the reliability of the instrument questionnaire data can be seen in the following table:

\section{Variable Preparation of Financial Statements}

\section{Table 5: The test results Reliability of Financial Statements}

Cronbach'sAlpha $\quad \mathrm{N}$ of Items

$0.729 \quad 85$

Source: SPSS processing results

The results of the above analysis shows that the alpha coefficient calculated for variable preparation of financial statements in the general perspective of $>0.60(0.729>0.60)$ so that it can be concluded that the questionnaire or gauge data for variable financial statements are reliable.

\section{Variable Value for Money}

Table 6: Reliability test results Value for Money

\begin{tabular}{ll}
\hline Cronbach'sAlpha & N of Items \\
\hline 0.859 & 85 \\
\hline
\end{tabular}

Source: SPSS processing results

The results of the above analysis shows that the alpha coefficient calculated for variable value for money> $0.60(0859>0.60)$ so that it can be concluded that the questionnaire or gauge data for the variable value for money to be reliable.

\section{Testing Hypotheses}

First Hypothesis Testing: The first hypothesis testing using correlation test. This test has the objective to determine the effect of education on students' perceptions of ethics and accounting in the financial statements.

In Table 7 below, the correlation between the variables "Ethics Education" with "Perception of Financial Statements" shows the figure of 0.058 This figure shows the correlation fairly and direction. With the number of probability relations between the two variables at $0.300<0.05$, the relationship between the two variables are not significant. To make a decision, we did test the first hypothesis as follows:

H0: There is no influence of variables and students' perceptions of ethics education in the preparation of financial statements.

Ha: There is the influence of variables and students' perceptions of ethics education in the preparation of financial statements.

Figures from the calculation of the probability Correlation is at $0.300<0.05$ then $\mathrm{H} 1$ is rejected. That is, there is no influence of variables and students' perceptions of ethics education in the preparation of financial statements. In other words, the first hypothesis in this study was rejected. 
Table 7: Correlations

\begin{tabular}{lllll}
\hline & & Perception & Ethics Education & Love of Money \\
\hline Pearson Correlation & $\begin{array}{l}\text { Perception } \\
\text { Ethics }\end{array}$ & 1.000 & .058 & .092 \\
& $\begin{array}{l}\text { Education } \\
\text { Love of } \\
\text { Money }\end{array}$ & .092 & 1.000 & -.001 \\
Sig. (1-tailed) & $\begin{array}{l}\text { Perception } \\
\text { Ethics }\end{array}$ & .000 & .300 & 1.000 \\
& $\begin{array}{l}\text { Education } \\
\text { Love of } \\
\text { Money }\end{array}$ & .201 & .495 & .201 \\
$\mathrm{~N}$ & $\begin{array}{l}\text { Perception } \\
\text { Ethics }\end{array}$ & 85 & 85 & .495 \\
& $\begin{array}{l}\text { Education } \\
\text { Love of } \\
\text { Money }\end{array}$ & 85 & 85 &. \\
& Source: SPSS processing results (processed) & 85 \\
\hline
\end{tabular}

The second hypothesis testing: Based on table 4.8 above, the correlation between the variables "Love of Money" with "Perception of Financial Statements" shows a figure of 0.092 this figure shows the correlation fairly and direction. With the number of probability relations between the two variables of $0.201<0.05$, the relationship between the two variables are not significant. To make a decision, we did test the following hypothesis:

H0: There is no influence of variables love of money and the perception of students in the preparation of financial statements.

Ha: There is the influence of variables love of money and the perception of students in the preparation of financial statements.

Figures from the calculation of the probability Correlation is $0,201<0.05$ then $\mathrm{H} 1$ is rejected. That is, there is no influence between variables love of money and the perception of students in the preparation of financial statements. In other words, the second hypothesis in this study was rejected.

Third Hypothesis Testing: Testing in this third hypothesis is different perceptions about the preparation of the financial statements between accounting students who have not taken courses accounting ethics education and students who have taken courses ethics education. The degree of trust for different test average was $95 \%$ and for the Mann Whitney test at $99 \%$, is the default for the test.

Table 8: Third Hypothesis Testing

\begin{tabular}{|c|c|c|c|}
\hline & & \multicolumn{2}{|c|}{$\begin{array}{l}\text { t-test for Equality of } \\
\text { Means }\end{array}$} \\
\hline & & $\mathbf{T}$ & Sig. (2-tailed) \\
\hline \multirow{2}{*}{$\begin{array}{l}\text { student } \\
\text { perceptions }\end{array}$} & Equal variances assumed & .450 & .654 \\
\hline & $\begin{array}{ll}\text { Equal variances } \\
\text { assumed }\end{array}$ & .450 & .654 \\
\hline
\end{tabular}

Source: SPSS processing results (processed)

To make a decision, we did test the third hypothesis as follows:

H0: There is no Differences in perception regarding the preparation of financial statements between accounting students who have not taken the ethics education courses and students who have taken courses accounting ethics education 
Ha: There are differences in the perception of the preparation of financial statements between accounting students who have not taken courses accounting ethics education and students who have taken courses ethics education.

Based on the calculations 4:10 table above shows that $\mathrm{t}$ for the preparation of financial statements is 0.450 with probability 0.654 . Therefore the probability of $>0.05$ then $\mathrm{H} 0$ is accepted and rejected Ha, which means there is no significant difference between the perceptions of students and students who have already taken courses ethics education in the preparation of financial statements.

\section{Conclusion and Recommendations}

Based on the description of the chapter discussion is the answer to the problems identified, the authors draw the following conclusion:

- Figures from the calculation of the probability of the correlation between the variables of 0.300 $<0.05$, the first hypothesis rejected. That is, there is no influence of variables and students' perceptions of ethics education in the preparation of financial statements.

- Figures from the calculation of the probability of the correlation between the variables of 0.201 $<0.05$, the second hypothesis rejected. That is, there is no influence of variables Love of money and perceptions of students in the preparation of financial statements.

- Figures from the calculation of the probability of the correlation between the variables of 0.201 $<0.05$, the third hypothesis rejected. That is, there are different perceptions about the preparation of the financial statements between accounting students who have not taken courses accounting ethics education and students who have taken courses ethics education

The results of this study are expected to provide information to academics about the ethics level students majoring in accounting to be used as a basis for preparing the accounting curriculum in realizing the development of the accounting profession in Indonesia towards a better and based on ethics. Because they found some colleges that do not include professional ethics courses. It also provides information to the Indonesian Institute of Accountants in particular compartment accountant accounting educators about student ethics as the basis for determining the policies to improve the quality of Indonesian accountant so as to improve the quality of financial reporting. Analysis of the ethics of students in the preparation of financial statements that are likely if students attend ethics education in their classrooms will get an explanation and understanding of the code of ethics an accountant. Ethics is important for students majoring in accounting, is devoted to final year students who will face the world of work, because if it became an accountant and accounting activities offender should not be falsified information about the financial statements. An accountant must have the accuracy and honesty in revealing everything related to events or activities that he check (reporting must be accountable).

Suggestions: Based on the above conclusions, and because of the limitations of this study, including samples of students not represent all universities in Indonesia, so the results cannot be generalized. Similarly, there may be a miss-perception questionnaire distributed so that the level of responses is relatively high, so the writer can give suggestion: Expanding the research object can add the study population and sample, for example, by comparing multiple students both students and non-accounting accounting (management) at a different university, but there is in the scope of Coordinator of Private Universities (Kopertis). This is likely to be more effective to assess the effectiveness of the accounting curriculum to changing perceptions of students in improving student ethics over financial reporting

\section{References}

IFAC No. 4http://www.ifac.org/sites/default/files/publications/files/20090115-IAESB_201013_Strategy_and_Work_Plan-V8R.pdf

Charismawati, Celvia Dhian. 2011. Analysis of the Relationship Between Love Of Money with Student Perceptions of Accounting Ethics. Available at http://eprints.undip.ac.id/29310/1/Skripsi012.pdf

Duska, Ronald F, and Brenda Shay D, 2011, Accounting Ethics. 2nd Edition, USA: Blackwell. 
Elias, RZ, 2008, Auditing Students' Commitment and anticipatory Professional Socialization and Their Relationship to Whistle blowing. Managerial Auditing Journal. 23(3).

Elias, R.Z. \& Magdy F. 2010, The relationship between accounting students' love of money and Reviews their ethical perception, Managerial Auditing Journal, Emerald Group Publishing, 25 (3), 269-281.

Fritzsche, David J, 2005, Business Ethics: A Global and Managerial Perspective, McGraw-Hill (F1 \& F2)

IAI, 2007, the Financial Accounting Standards, Salemba Four, Jakarta.

IFAC No. 4http://www.ifac.org/sites/default/files/publications/files/20090115-IAESB_201013_Strategy_and_Work_Plan-V8R.pdf

Intani, L. and E. S. Suhendra, 2009, Analysis of Effect of Ethics Education and Student Perceptions In the Preparation of Financial Statements. Available at http: //www.gunadarma.ac.id/library/articles/graduate/economy/2009/Artikel_20205731.pdf

Nunnally, J.C., 1978. Psychometric Theory. McGraw-Hill, New York.

Rahmawati, S. and Sulardi, 2003, 'Ethical Perceptions of Accounting Educators, Students and Managers Accounting for Earnings Management Practices (Survey in Surakarta)', Journal of Accounting and Business, Vol. 3, No. 2, pp. 146-159.

Robbins, Stephen P. 2008. Organizational Behavior. Book 1, Issue 12. Translated by Diana Angelica. Jakarta: Salemba Four.

SFAC No. 2 http://cpaclass.com/gaap/sfac/gaap-sfac-2.htm

Sugiyono, 2008, Statistics for Research, Publisher Alfabeta, Bandung.

Tang, et al, 2004, Does the love of money is moderate and mediate the income-pay relationship satisfaction? Journal of Managerial Psychology, 19(2), 111-135.

Tang, Thomas \& Yuh-Jia Chen, 2006, the Attitude Toward and propensity to Engage in Unethical Behavior: Measurement invariance across Major Among University Students, Journal of Business Ethics, Springer, 69 (1), 77-93.

Tang, Thomas, 2007, Income and Quality of Life: Does the Love of Money Make a Difference? Journal of Business Ethics, Springer, 72 (4), 375-393.

Tang, Thomas \& Yuh-Jia Chen, 2008, Intelligence Vs. Wisdom: The Love of Money, Machiavellianism, and Unethical Behavior across College Major and Gender, Journal of Business Ethics, Springer, 82 (1), 126.

Wyatt, AR, 2004, the Accounting Professionalism - They just do not get it! Accounting Horizons, 18, 45-53. 